\title{
Regulation of Early Human Growth: Impact on Long-Term Health
}

\author{
Berthold Koletzko Michael Chourdakis Veit Grote Christian Hellmuth \\ Christine Prell Peter Rzehak Olaf Uhl Martina Weber
}

Division of Metabolic and Nutritional Medicine, Dr. von Hauner Children's Hospital, Ludwig Maximilians

University of Munich, Munich, Germany

\section{Key Words}

Human growth trajectories · Infant nutrition · Obesity

prevention · Metabolomics · Epigenetics

\begin{abstract}
Growth and development are central characteristics of childhood. Deviations from normal growth can indicate serious health challenges. The adverse impact of early growth faltering and malnutrition on later health has long been known. In contrast, the impact of rapid early weight and body fat gain on programming of later disease risk have only recently received increased attention. Numerous observational studies related diet in early childhood and rapid early growth to the risk of later obesity and associated disorders. Causality was confirmed in a large, double-blind randomised trial testing the 'Early Protein Hypothesis'. In this trial we found that attenuation of protein supply in infancy normalized early growth and markedly reduced obesity prevalence in early school age. These results indicate the need to describe and analyse growth patterns and their regulation through diet in more detail and to characterize the underlying metabolic and epigenetic mechanisms, given the potential major relevance for public health and policy. Better understanding of growth patterns and their regulation could have major benefits for the promotion of public health, consumer-orientated nutrition recommendations, and the development of improved food products for specific target populations.
\end{abstract}

(c) 2014 S. Karger AG, Basel

\section{KARGER}

E-Mail karger@karger.com

www.karger.com/anm

\section{Introduction}

Growth and development are central characteristics of childhood. Growth can be characterised quantitatively as a gain in length or height, head circumference, body mass or other measures. The importance of regular monitoring of children's growth patterns as part of standard paediatric health care and of research studies, e.g. by plotting repeated growth measures on percentile references, is widely acknowledged $[1,2]$. Up- and downward deviations of growth from normal patterns, based on growth standards or percentile curves, may reflect grave disorders, such as genetic, syndromic or endocrine conditions, infectious or inflammatory diseases, malnutrition, psychosocial deprivation or abuse, or a broad spectrum of other disorders. Based on the results of the Multicentre Growth Reference Study (MGRS), which collected data points on about 8,500 children in six countries around the globe (Brazil, Ghana, India, Norway, Oman and the USA), the World Health Organisation takes the view that a single set of growth curves adequately describes normal growth of all economically advantaged breastfed infants and children up to an age of 5 years $[3,4]$. However, a recent systematic review on growth data from studies performed in 55 countries or ethnic groups found that growth varied among different national and ethnic groups [5]. Means of height were generally within 0.5 of the standard deviation (SD) of the MGRS means, whereas weight varied by as

Prof. Berthold Koletzko

Division of Metabolic and Nutritional Medicine, Dr. von Hauner Children's Hospital Ludwig Maximilians University of Munich

Lindwurmstrasse 4, DE-80337 Munich (Germany)

E-Mail office.koletzko@med.uni-muenchen.de 
much as $1.5 \mathrm{SD}$. Mean head circumference values also varied widely, with means in many groups consistently $0.5-1$ SD above the MGRS mean. Of interest, head size in breastfed children at any age examined was found to be far closer to local norms than to the MGRS mean [5]. These data question whether the use of one single international growth standard is justified and call for further work aiming at a better understanding of the predictors and regulators of child growth.

Early growth faltering and malnutrition have long been known to induce adverse later outcomes, such as poor cognitive and motor function [6, 7]. In contrast, the adverse effects of excessive growth and in particular of rapid weight and body fat gain on long-term health have only recently received increased attention. It is now widely recognized that early growth and tissue development during the first 1,000 days of human life and beyond from conception through to early childhood - are important predictors of long-term health and performance up to adulthood and old age (Early Metabolic Programming of Lifelong Health, Developmental Origins of Adult Health) [8-13]. Therefore, the study of child growth receives increasing interest.

\section{Infant Diet, Early Growth and Later Obesity}

A relationship between diet in early childhood, rapid early growth and later outcomes has been found in many studies. More than 1 decade ago, our group showed in a large cross-sectional study including more than 9,000 children in Germany that breastfed children have a markedly reduced later risk of obesity at school age than previously bottle (formula)-fed children, with an inverse doseresponse relationship between breastfeeding duration and the adjusted odds ratios for obesity (fig. 1) [14]. This finding was subsequently confirmed in numerous cohort studies and meta-analyses [15-18], which has markedly influenced policy on breastfeeding promotion worldwide $[12,19-21]$. We hypothesized that breastfeeding protects through reducing weight gain velocity during early childhood, resulting from a different substrate supply with breastfeeding compared to feeding conventional infant formula, in particular the markedly lower protein content in human milk than in infant formula $[22,23]$. Indeed, rapid weight gain during the first 2 years of life is highly predictive of overweight at early school age [24], which was confirmed in numerous other studies: an increase in weight-for-age SD score $>0.67$ SD during the 1 st and 2 nd year of life predicts two- to threefold increased odds of

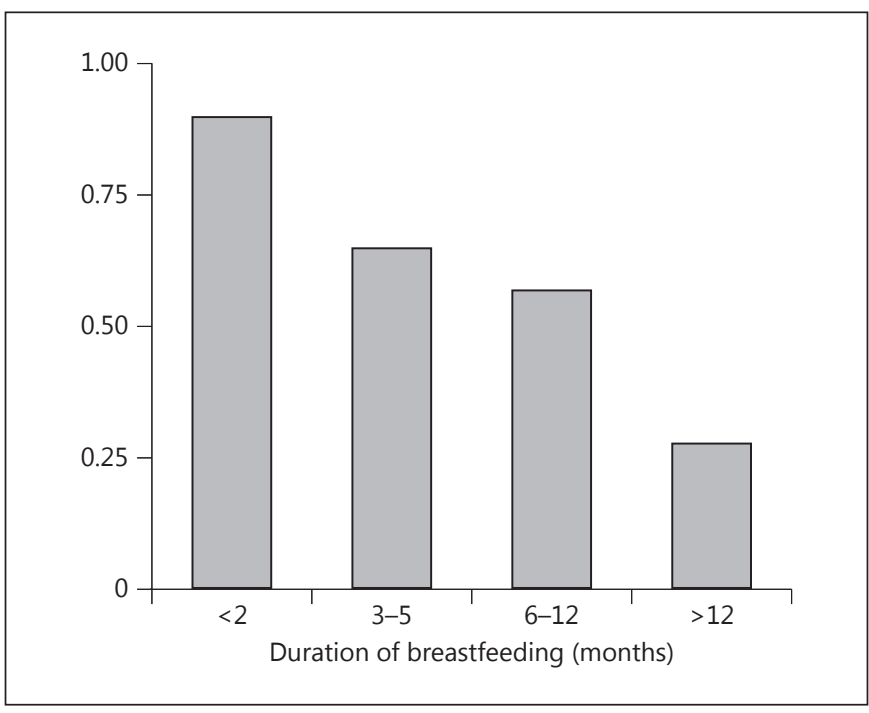

Fig. 1. Longer duration of breastfeeding is linked to a lower adjusted odds ratio of obesity at early school age. Data from a crosssectional study in more than 9,000 children in Bavaria, Germany [14].

obesity in children, teenagers and adults [25]. A recent systematic review and meta-analysis of 15 studies examining body composition in healthy infants showed that breastfed infants had a lower body fat mass at age 1 year than formula-fed infants [26]. Accordingly, we recently found that weight gain velocity during the first 6 months of life is closely correlated to infant body fat mass, as assessed by isotope dilution (deuterium method), whereas lean body mass is not related to weight gain velocity [27]. It seems likely that variation in substrate supply is the causative factor. It is of key importance to elucidate the underlying mechanisms and which substrates are the major modulators of early growth.

\section{The Early Protein Hypothesis}

We explored 'The Early Protein Hypothesis' (fig. 2): high protein supply in infancy increases plasma and tissue concentrations of amino acids that stimulate an enhanced secretion of the growth factors insulin-like growth factor-1 (IGF-1) and insulin, with consecutively increased weight gain in the first 2 years of life, increased adipogenic activity, and increased long-term risk of later obesity and associated disorders [10, 28, 29]. We tested this Early Protein Hypothesis in a large, multicentre randomised controlled trial consecutively funded by the European Commission Framework Programmes, the Child- 
Table 1. Prevalence and relative risk of obesity at the age of 6 years in children participating in the multicentre CHOP trial who had been randomised to receive conventional formula with high protein content (control) or intervention formula with reduced protein but equal energy content

\begin{tabular}{lll}
\hline Intervention: lower protein & $4.4 \%$ & \\
\hline Control: higher protein & $10 \%$ & \\
\hline Unadjusted relative risk & 2.43 & $\mathrm{p}=0.024$ \\
& $95 \% \mathrm{CI}: 1.12-5.27$ & \\
\hline Adjusted relative risk & 2.87 & $\mathrm{p}=0.016$ \\
& $95 \% \mathrm{CI}: 1.22-6.75$ & \\
\hline Breastfed reference group & $2.9 \%$ & \\
\hline
\end{tabular}

A group of breastfed children was followed for reference. Lower protein supply in infancy reduced the risk for obesity at early school age 2.43-fold (unadjusted) or 2.87-fold (adjusted), respectively [31].

hood Obesity Project (CHOP) Trial [30, 31]. In this trial, we enrolled 1,678 healthy term infants born appropriate for gestational age that were either exclusively breastfed for at least the first 3 months of life (by parental choice) or formula fed; the latter were randomised double blind to receive during the 1st year of life milk formulas with equal content of energy and most nutrients, but either (conventionally) high or reduced protein contents. Reducing protein supply with infant formula normalised growth measures at 2 years of age relative to the breastfed reference group and the WHO growth standards. Higher protein intake induced significantly increased weight for length and body mass index (BMI) in early childhood [32]. Follow-up of subjects up to school age demonstrates lasting large effects of early substrate supply and growth on later health. At 6 years of age, previously breastfed children have a much lower BMI than those fed conventional formula with high protein contents (fig. 3), which agrees with results of observational studies [33]. In contrast, children who had been double-blind randomised to receive experimental formula with reduced protein but equal energy content in the 1st year of life have a significantly lower BMI than those in the control group with conventional formula, and they achieve a BMI which is not different from the breastfed reference group [31]. There was a very large effect of early feeding and growth on the risk of obesity at age 6 years: Lower protein supply in infancy reduced the risk for obesity at early school age 2.43-fold (unadjusted) or 2.87-fold (adjusted), respectively [31] (table 1).

Early Growth and Long-Term Health

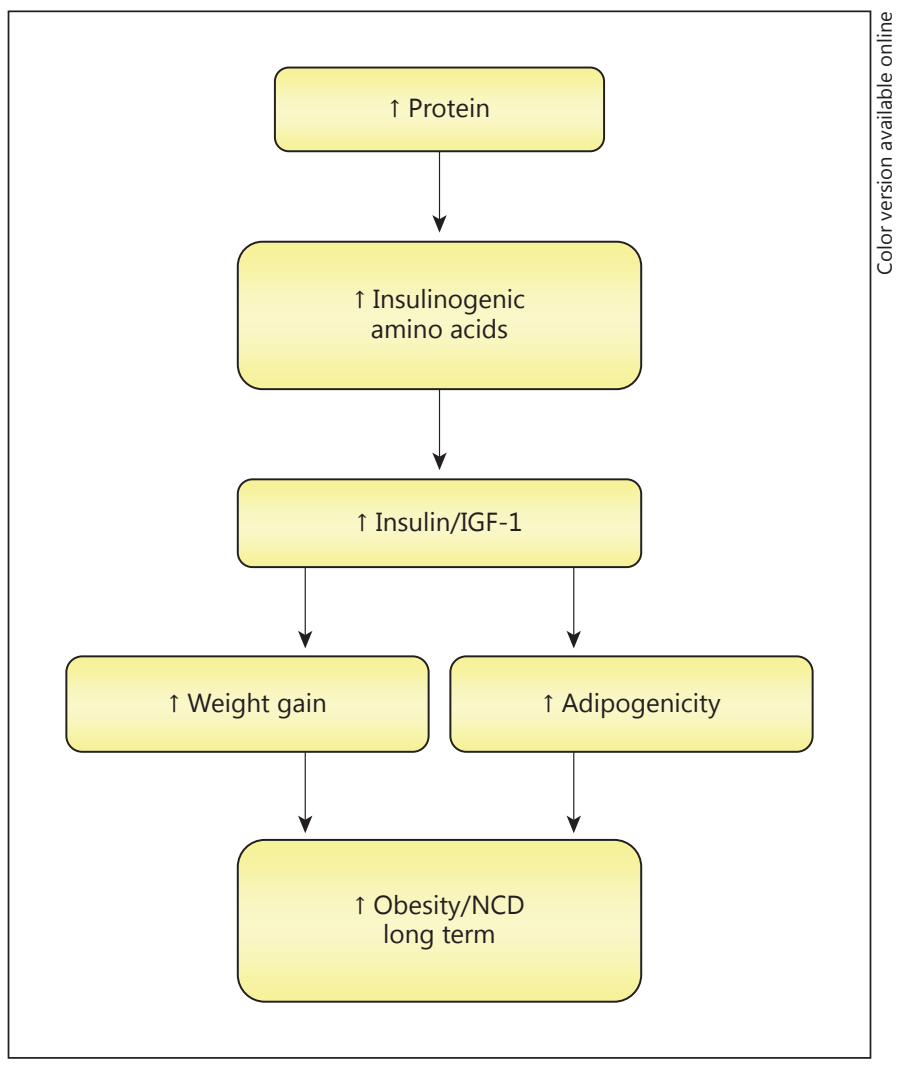

Fig. 2. The Early Protein Hypothesis stipulates that a high infant protein supply in excess of metabolic requirements increases plasma and tissue concentrations of amino acids that stimulate an enhanced secretion of the growth factors IGF-1 and insulin, with consecutively increased weight gain in the first 2 years of life, increased adipogenic activity and increased long-term risk of later obesity and associated non-communicable diseases (NCD) such as diabetes mellitus type 2 [10].

These data demonstrate that metabolic modulation of early growth has a very large impact on later obesity prevalence, which indicates major opportunities for disease prevention and public health promotion. Therefore, it is of paramount importance to investigate and understand the underlying mechanisms and key drivers through which early metabolic exposure modulates child growth and long-term health, which also requires meaningful description of the kinetics of child growth.

\section{Metabolic Mechanisms}

In our randomised $\mathrm{CHOP}$ Trial, a higher formula protein supply to infants induced markedly elevated plasma concentrations of the branched-chain amino ac- 
Fig. 3. Evolution of mean BMI from early infancy to the age of 6 years in children with different infant feeding regimens participating in the multicentric CHOP trial. Previously breastfed children have a lower BMI than those fed conventional formula with high protein contents. In contrast, children who had been double-blind randomised to receive experimental formula with reduced protein but equal energy content (lower protein) in the 1st year of life have a significantly lower BMI than those in the control group with conventional formula, and they achieve a BMI equal to that of the breastfed reference group [31].

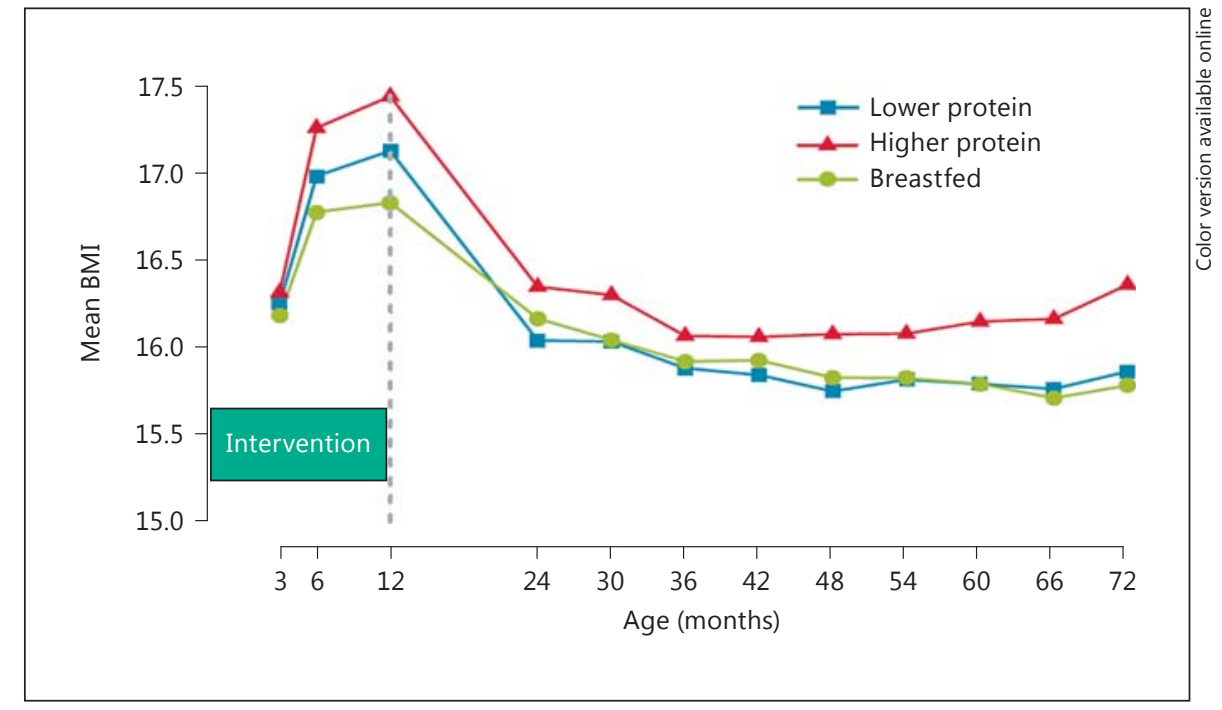

ids leucine, isoleucine and valine, along with slight elevations in other indispensable amino acids [34]. In contrast, high protein supply did not change the plasma concentrations of most other amino acids, and even reduced the plasma concentrations of glutamine and glycine. We hypothesise that enhanced concentrations of branched-chain amino acids in response to protein supply may be causative for inducing excessive weight gain and higher body fat mass in formula-fed compared to breastfed subjects. Experimental observations provide support for a potential key role of amino acids in growth regulation [25]. Verification of this hypothesis would allow new avenues to early obesity prevention by modifying specifically the amino acid composition of feed, rather than reducing further the total protein intake, which has considerable limitations for practical and safety reasons.

In fact, amino acids have been shown to be more potent stimulators of IGF-1 release than glucose in fetal rat islets [35]. Studies in 4-week-old rats showed that feeding a diet with 15 instead of $5 \%$ protein for only 1 week increased serum IGF-1 more than fourfold [36]. Amino acids also markedly influence insulin secretion with key regulatory roles for anabolic pathways and lipid deposition during early growth $[37,38]$. Glucose is a key driver of insulin secretion, but glucose-induced insulin secretion is markedly attenuated by low protein supply. Also, leucine and most likely also other amino acids enhance insulin secretion via both acute effects, such as activated glutamate dehydrogenase activity, as well as chronic effects, such as gene transcription and regulation of $\beta$ cell metabolism [39]. One pathway through which amino acids and the growth factors insulin and IGF-1 could effectively modulate metabolic response and growth in children is the mammalian target of rapamycin (mTOR), a highly conserved Ser/Thr kinase present in two structurally and functionally distinct complexes (fig. 4) [40]. The growth factors insulin and IGF-1 stimulate mTORC2 via an unknown pathway, and mTORC1 via phosphoinositide 3-kinase (PI3K) and Akt inducing the mTORC1 activator Rheb. Amino acids enhance ATP loading of RAG proteins and RAG-GTPases, which interact with Rheb and activate mTORC1 [40]. Of importance, full activation of mTORC1 is only achieved through the synergistic action of both growth factors and amino acids, while a low energy supply downregulates mTORC1 [40]. Thus, this pathway represents an elaborate sensor system by which nutritional supply regulates metabolism and growth. The enormous power of this system is demonstrated, for example, in mice with knockout of raptor in adipose tissue, which leads to disruption of mTORC1. These mice are lean and resistant to diet-induced obesity, and they have improved metabolic characteristics, such as better glucose tolerance and insulin sensitivity, as well as resistance to diet-induced hypercholesterolaemia [41]. These observations lead us to the conclusion that regulation of mTORC1 signalling by amino acids may control whole body energy metabolism, body weight and body fat deposition. This hypothesis needs to be tested by detailed metabolic characterisation of prospective cohorts in which precise phenotyping of growth has been performed and in which informative biomarkers of nutritional expo- 
Fig. 4. Simplified scheme of nutrient sensing by mTOR and its regulatory signalling for metabolism and growth. Amino acids and the growth factors insulin and IGF-1 modulate metabolic response and growth through mTOR. Insulin and IGF-1 stimulate mTORC2 via an unknown pathway, and $\mathrm{mTORC} 1$ via PI3K and protein kinase $\mathrm{B}$ (Akt) inducing the mTORC1 activator Rheb (GTP-binding protein Rheb). Amino acids enhance ATP loading of RAG proteins and RAG-GTPases, which interact with Rheb and activate mTORC1. A low energy supply downregulates mTORC1. mTORC1 effects the regulators of protein translation 4E-BP and S6K. Activation of mTORC2 induces phosphorylation of the AGC protein kinases Akt, serum- and glucocorticoid-induced kinase (SGK1) and protein kinase $\mathrm{C}$ (PKC), which modulate cell survival, metabolic response and cytoskeletal organisation.

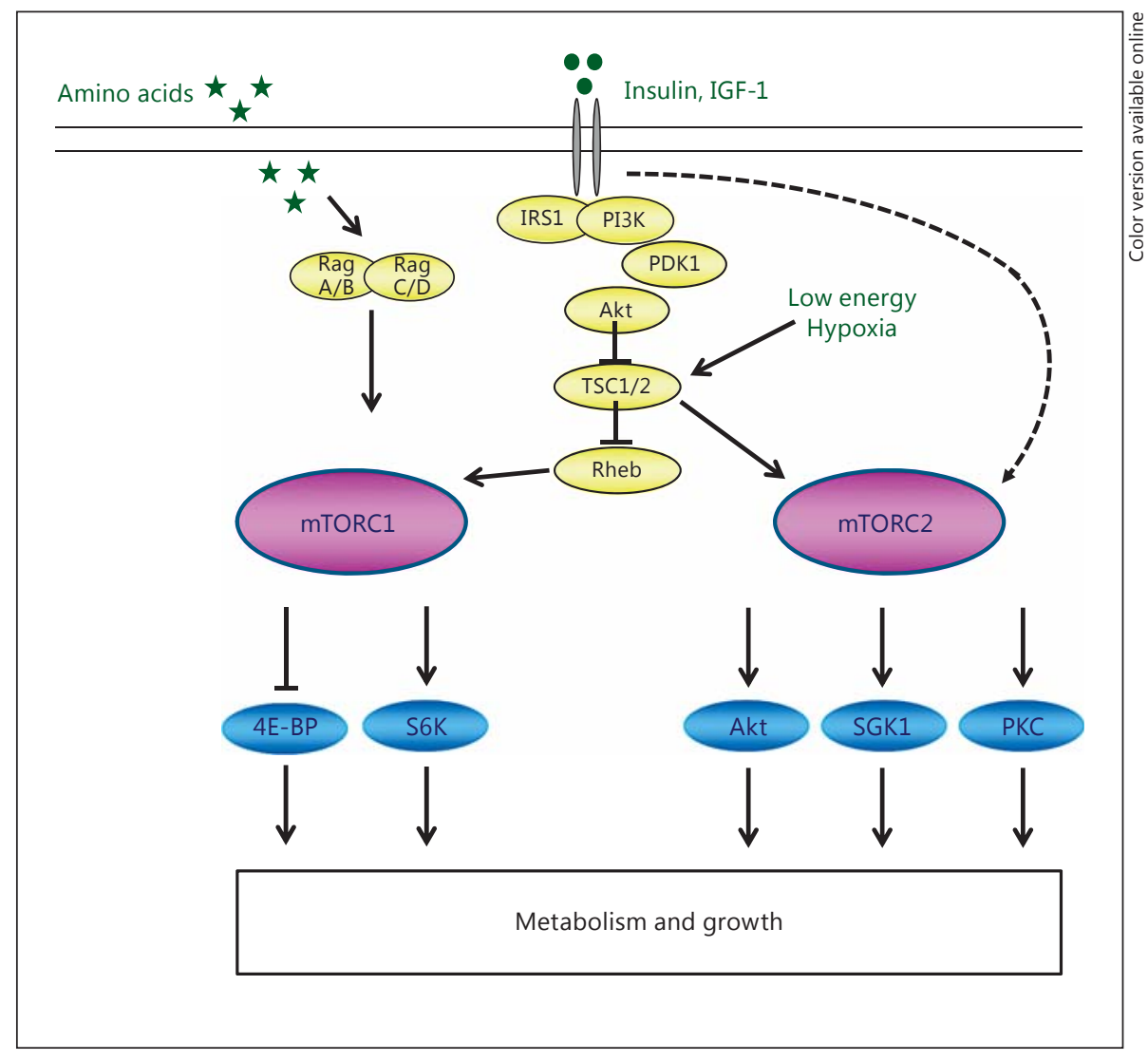

sure, status, function, growth and other effects are determined [42].

This approach has now become feasible with established high-throughput, precise analytical tools for targeted metabolomic profiling from minimal sample volumes using flow injection analysis with triple-quad mass spectrometry, which is extremely powerful [43-49]. Application of these sophisticated tools bears the very promising potential to detect relevant but as yet unidentified regulatory substrates involved in the modulation of growth and body composition.

\section{Do Epigenetic Mechanisms Regulate Growth?}

Epigenetic modifications might be the missing link between the metabolic environment and alterations in gene expression inducing persistent later effects. Epigenetics is the study of heritable changes in gene expression not caused by changes in the DNA sequence, but by biochemical modifications of DNA that determine whether or not genes are expressed. Epigenetic mechanisms control modifications in chromatin, regulate its accessibility to transcription factors and thus contribute to determine the level of expression of different genes. Mechanisms of epigenetic modification include the addition of methyl groups to DNA cytosine bases [50], the addition of methyl and acetyl groups to proteins (histones) around which DNA is folded [51] and interfering microRNA [52, 53]. Recently, interest in epigenetic research in relation to disease, development and aging has increased $[9,54,55]$. The available evidence for epigenetic effects of nutrition in animal models and first human studies are based on alterations in DNA methylation, where powerful analytical methodology for human genome-wide analysis has now become available.

Addition of a methyl group to the $5^{\prime}$ carbon of a cytosine base in the context of $\mathrm{CpG}$ is the most frequent and stable form of epigenetic modification that does not affect primary DNA sequence, but affects secondary interactions, which play a critical role in the regulation of gene expression. Normally, genes are expressed when transcriptions factors bind to DNA and activate the gene. DNA methylation prevents transcription factor 
binding while it favours the binding of transcriptioninhibiting proteins and is therefore mostly associated with switching genes 'off. The degree of activation of a given gene generally depends upon its degree of methylation. Accumulating evidence from animal studies and from some first albeit limited studies in humans point to the possibility that differences in DNA methylation patterns, and potentially other epigenetic processes, are the 'missing link' in the 'Early Origins of Later Disease Hypothesis'.

It has been shown that differentially methylated regions (DMR) are often the result of perturbations of the environment in sensitive or critical early periods of life (periconceptional and postnatal periods, and puberty), which can lead to alternative pathways of cell and organ development ('developmental plasticity') [9, 56, 57], and that can enhance the susceptibility of later diseases (e.g. obesity, diabetes or cancer). Methylation is principally reversible [58], e.g. by nutritional intervention. For example, folate or genistein supplementation can counteract bisphenol-A-induced DNA hypomethylation and the change in the coat colour phenotype in mice [59]. Such nutritional reprogramming of genetic and metabolic expression may even be induced transgenerationally, e.g. by paternal diet in combination with a low-protein diet of the offspring mice [60]. At this time, it is not known how stable nutrient-induced alterations are over time, i.e. whether and to which extent they show alterations in humans followed up over several years. Thus, exploring epigenetic markers over time may be a very important path for exploring future strategies of individual disease prevention and perhaps even treatment.

Nutritional effects on DMR so far have been mostly studied in animal models with a focus on folate supply and on caloric restrictions as determinants, but only to a very limited extent in humans $[61,62]$. A relation to adiposity was recently reported in a single study that assessed methylation status of $68 \mathrm{CpG}$ sites from five candidate genes in umbilical cord tissue DNA from healthy neonates using Sequenom MassARRAY, which explored maternal pregnancy diet and child's adiposity at age 9 years in two cohorts [63]. In both cohorts, higher retinoid $\mathrm{X}$ receptor- $\alpha$ chr9:136355885+ methylation was associated with childhood fat mass, and in one cohort also with lower maternal carbohydrate intake in early pregnancy. Regression analyses including sex and neonatal epigenetic markers explained $>25 \%$ of the variance in childhood adiposity. Thus, programming effects of early nutrition and metabolic exposure may be mediated through altered
DMR, which thus needs to be explored in greater detail and with the much more powerful genome-wide methods that are now available.

There is only limited information on the effects of protein intake on DMR from animal studies. A recent review on epigenetic programming of diabetes and obesity [64] identified 14 animal studies from 1999 to 2011 focussing on protein exposure during the fetal or neonatal period, and the impact on the obesity and diabetes risk mediated by epigenetic modifications. Of importance, the dietary interventions used in these animal studies generally tend to be extreme and are hardly comparable to the types of exposures observed in contemporary human populations. Several animal studies in rat and mouse models showed that the effects of very low maternal protein intake in pregnancy on later obesity of the offspring in puberty or adulthood, or even trans-generationally, are mediated by hypo- or hypermethylation mostly in promoter regions of different genes (e.g. PPARa, IGF2/ H19 locus, Leptin or PEPCK) or gene receptors (GR, LXR or IR).

So far, there are only very few genome-wide DNA methylation studies in relation to protein intake in animals [65], while there is accumulating evidence that protein intake during pregnancy and in the postnatal period affects the methylation status of various genes and may indeed be a diet-induced mediating factor for later obesity $[60,66-76]$. However, so far, there is not a single study in humans on protein intake and DNA methylation, nor are there any studies on the mediating effects of DMR regarding protein intake and growth or body composition.

Limited existing studies explored mediating effects of DNA methylation on rapid growth and obesity in adolescence [77]. In three studies, mediating effects of maternal folate intake in early pregnancy on birth weight were explored [78, 79]. Fryer et al. [78] performed a genomewide methylation study. A further genome-wide study analysed the effect of the FTO gene on obesity mediated by DMR [80]. Some epigenetic studies analysed mediating effects of DMR in placental tissue regarding intrauterine growth restriction and fetal growth [81].

\section{Conclusions}

The description and analysis of growth patterns and their regulation through diet, and the potentially underlying metabolic and epigenetic mechanisms are of major relevance for public health and policy, and have the po- 
tential to contribute greatly to promoting health and well-being in the population [82]. Hence, it is important to address these questions in large prospective cohort studies with detailed phenotyping of growth, markers of body composition as well as available biosamples that allow assessment of markers with state-of-the-art methodology. Groundbreaking research with the use of unconventional, new and sophisticated methodology is needed that goes significantly beyond the state of the art. Research collaboration of academic investigators and researchers from industry in this field has the potential to increase outputs and success [83]. If successful, the results of such research should provide answers to key questions on the regulation of growth, with major benefit for scientific understanding, opportunities for future research, promotion of public health, nutrition recommendations and development of improved food products.

\section{Acknowledgements}

Work reported herein is carried out with partial financial support from the Commission of the European Communities, the 7th Framework Programme, contract FP7-289346-EarlyNutrition and the European Research Council Advanced Grant ERC-2012AdG - No. 322605 META-GROWTH. This paper does not necessarily reflect the views of the Commission and in no way anticipates the future policy in this area. Funding for the workshop 'Analysis of Child Growth Trajectories' held at the Center of Advanced Studies, Ludwig Maximilians University of Munich, Germany, in 2013 has been granted by the Center of Advanced Studies, Ludwig Maximilians University of Munich, Deutsche Forschungsgemeinschaft (German Research Council, Rz 70/3-1), Bonn, Germany, International Life Science Institute Europe, Brussels, Belgium, Abbott Nutrition, Granada, Spain, ILSI, and Nestlé Nutrition, Vevey, Switzerland.

\section{Disclosure Statement}

The authors declare no conflicts of interest in relation to the content of this paper.

\section{References}

1 Michaelsen KF: Child growth; in Koletzko B, Cooper P, Garza C, Makrides M, Uauy R, Wang W (eds): Pediatric Nutrition - A Practical Reference Guide. Basel, Karger, 2008.

-2 Ward LC, Poston L, Godfrey KM, Koletzko B: Assessing early growth and adiposity: report from an EarlyNutrition Academy workshop. Ann Nutr Metab 2013;63:120-130.

- 3 de Onis M, Onyango A, Borghi E, Siyam A, Blossner M, Lutter C; WHO Multicentre Growth Reference Study Group: Worldwide implementation of the WHO child growth standards. Public Health Nutr 2012;15:16031610.

4 de Onis M, Siyam A, Borghi E, Onyango AW, Piwoz E, Garza C: Comparison of the World Health Organization growth velocity standards with existing US reference data. Pediatrics 2011;128:e18-e26.

5 Natale V, Rajagopalan A: Worldwide variation in human growth and the World Health Organization growth standards: a systematic review. BMJ Open 2014;4:e003735.

6 Chang SM, Walker SP, Grantham-McGregor S, Powell CA: Early childhood stunting and later fine motor abilities. Dev Med Child Neurol 2010;52:831-836.

7 Walker SP, Chang SM, Powell CA, Simonoff E, Grantham-McGregor SM: Early childhood stunting is associated with poor psychological functioning in late adolescence and effects are reduced by psychosocial stimulation. J Nutr 2007; 137:2464-2469.
8 Barker DJ: The fetal and infant origins of disease. Eur J Clin Invest 1995;25:457-463.

-9 Gluckman PD, Hanson MA, Cooper C, Thornburg KL: Effect of in utero and earlylife conditions on adult health and disease. $\mathrm{N}$ Engl J Med 2008;359:61-73.

10 Koletzko B, Symonds ME, Olsen SF: Programming research: where are we and where do we go from here? Am J Clin Nutr 2011;94: 2036S-2043S

-11 Symonds ME, Mendez MA, Meltzer HM, Koletzko B, Godfrey K, Forsyth S, van der Beek EM: Early life nutritional programming of obesity: mother-child cohort studies. Ann Nutr Metab 2013;62:137-145.

12 Koletzko B, Bauer CP, Bung P, Cremer M, Flothkotter M, Hellmers C, Kersting M, Krawinkel M, Przyrembel H, Rasenack R, Schafer T, Vetter K, Wahn U, Weissenborn A, Wockel A: German national consensus recommendations on nutrition and lifestyle in pregnancy by the 'Healthy Start - Young Family Network'. Ann Nutr Metab 2013;63:311-322.

13 Patro B, Liber A, Zalewski B, Poston L, Szajewska H, Koletzko B: Maternal and paternal body mass index and offspring obesity: a systematic review. Ann Nutr Metab 2013;63:3241.

14 von Kries R, Koletzko B, Sauerwald T, von Mutius E, Barnert D, Grunert V, von Voss H: Breast feeding and obesity: cross sectional study. BMJ 1999;319:147-150.
15 Arenz S, Ruckerl R, Koletzko B, von Kries R: Breast-feeding and childhood obesity - a systematic review. Int J Obes Relat Metab Disord 2004;28:1247-1256.

$\checkmark 16$ Harder T, Plagemann A: Re: Duration of breastfeeding and risk of overweight: a metaanalysis - response. Am J Epidemiol 2006; 163:872A-873A.

17 Owen CG, Martin RM, Whincup PH, Smith GD, Cook DG: Effect of infant feeding on the risk of obesity across the life course: a quantitative review of published evidence. Pediatrics 2005;115:1367-1377

18 Weng SF, Redsell SA, Swift JA, Yang M, Glazebrook CP: Systematic review and metaanalyses of risk factors for childhood overweight identifiable during infancy. Arch Dis Child 2012;97:1019-1026.

19 ESPGHAN Committee on Nutrition, Agostoni C, Braegger C, Decsi T, Kolacek S, Koletzko B, Michaelsen KF, Mihatsch W, Moreno LA, Puntis J, Shamir R, Szajewska H, Turck D, van Goudoever J: Breast-feeding: a commentary by the ESPGHAN Committee on Nutrition. J Pediatr Gastroenterol Nutr 2009; 49:112-125.

20 Lutter CK, Morrow AL: Protection, promotion, and support and global trends in breastfeeding. Adv Nutr 2013;4:213-219.

21 Health Canada; Canadian Paediatric Society; Dietitians of Canada; Breastfeeding Committee for Canada: Nutrition for healthy term infants: recommendations from birth to six months. Can J Diet Pract Res 2012;73:204. 
-22 Koletzko B, Broekaert B, Demmelmair H, Franke J, Hannibal I, Oberle D, Schiess S, Baumann BT, Verwied-Jorky S: Protein intake in the first year of life: a risk factor for later obesity? The EU Childhood Obesity Project; in Koletzko B, Dodds P, Akerblom H, Ashwell M (eds): Advances in Experimental Medicine and Biology: Perinatal Programming of Adult Health - EC Supported Research. Berlin, Springer, 2005, pp 69-79.

23 Koletzko B, von Kries R, Closa R, Escribano J, Scaglioni S, Giovannini M, Beyer J, Demmelmair H, Anton B, Gruszfeld D, Dobrzanska A, Sengier A, Langhendries JP, Rolland Cachera MF, Grote V: Can infant feeding choices modulate later obesity risk? Am J Clin Nutr 2009;89:1502S-1508S.

24 Toschke AM, Grote V, Koletzko B, von Kries $\mathrm{R}$ : Identifying children at high risk for overweight at school entry by weight gain during the first 2 years. Arch Pediatr Adolesc Med 2004;158:449-452.

-25 Koletzko B, Beyer J, Brands B, Demmelmair H, Grote V, Haile G, Gruszfeld D, Rzehak P, Socha P, Weber M; European Childhood Obesity Trial Study Group: Early influences of nutrition on postnatal growth; in Gillman M, Gluckman P, Rosenfeld R (eds): Recent Advances in Growth Research: Nutritional, Molecular and Endocrine Perspectives. Basel, Karger, 2013, pp 11-27.

-26 Gale C, Logan KM, Santhakumaran S, Parkinson JR, Hyde MJ, Modi N: Effect of breastfeeding compared with formula feeding on infant body composition: a systematic review and meta-analysis. Am J Clin Nutr 2012;95: 656-669.

-27 Escribano J, Luque V, Ferre N, Mendez-Riera G, Koletzko B, Grote V, Demmelmair H, Bluck L, Wright A, Closa-Monasterolo R: Effect of protein intake and weight gain velocity on body fat mass at 6 months of age: the EU Childhood Obesity Programme. Int J Obes (Lond) 2012;36:548-553.

28 Brands B, Demmelmair H, Koletzko B, The EarlyNutrition Project: How growth due to infant nutrition influences obesity and later disease risk. Acta Paediatr 2014;103:578-585.

29 Koletzko B, von Kries R, Monasterolo RC, Subias JE, Scaglioni S, Giovannini M, Beyer J, Demmelmair H, Anton B, Gruszfeld D, Dobrzanska A, Sengier A, Langhendries JP, Cachera MF, Grote V: Infant feeding and later obesity risk. Adv Exp Med Biol 2009;646: $15-29$.

-30 Koletzko B, von Kries R, Closa R, Escribano J, Scaglioni S, Giovannini M, Beyer J, Demmelmair H, Gruszfeld D, Dobrzanska A, Sengier A, Langhendries JP, Rolland Cachera MF, Grote V: Lower protein in infant formula is associated with lower weight up to age $2 \mathrm{y}$ : a randomized clinical trial. Am J Clin Nutr 2009;89:1836-1845.
Weber M, Grote V, Closa-Monasterolo R, Escribano J, Langhendries JP, Dain E, Giovannini M, Verduci E, Gruszfeld D, Socha P, Koletzko B; European Childhood Obesity Trial Study Group: Lower protein content in infant formula reduces BMI and obesity risk at school age: follow-up of a randomized trial. Am J Clin Nutr 2014;99:1041-1051.

32 Koletzko B, von Kries R, Closa R, Escribano J, Scaglioni S, Giovannini M, Beyer J, Demmelmair H, Gruszfeld D, Dobrzanska A, Sengier A, Langhendries JP, Rolland Cachera MF, Grote V; European Childhood Obesity Trial Study Group: Lower protein in infant formula is associated with lower weight up to age 2 y: a randomized clinical trial. Am J Clin Nutr 2009;89:1836-1845.

-33 Thorisdottir B, Gunnarsdottir I, Thorisdottir AV, Palsson GI, Halldorsson TI, Thorsdottir I: Nutrient intake in infancy and body mass index at six years in two population-based cohorts recruited before and after revision of infant dietary recommendations. Ann Nutr Metab 2013;63:145-151.

34 Socha P, Grote V, Gruszfeld D, Janas R, Demmelmair H, Closa-Monasterolo R, Subias JE, Scaglioni S, Verduci E, Dain E, Langhendries JP, Perrin E, Koletzko B; European Childhood Obesity Trial Study Group: Milk protein intake, the metabolic-endocrine response, and growth in infancy: data from a randomized clinical trial. Am J Clin Nutr 2011;94:1776S1784S.

35 Hogg J, Han VK, Clemmons DR, Hill DJ: Interactions of nutrients, insulin-like growth factors (IGFs) and IGF-binding proteins in the regulation of DNA synthesis by isolated fetal rat islets of Langerhans. J Endocrinol 1993;138:401-412.

36 Ketelslegers JM, Maiter D, Maes M, Underwood LE, Thissen JP: Nutritional regulation of insulin-like growth factor-I. Metabolism 1995;44:50-57.

-37 Newsholme P, Gaudel C, McClenaghan NH: Nutrient regulation of insulin secretion and beta-cell functional integrity. Adv Exp Med Biol 2010;654:91-114.

38 Muntoni S: Insulin resistance: pathophysiology and rationale for treatment. Ann Nutr Metab 2011;58:25-36.

39 Yang J, Chi Y, Burkhardt BR, Guan Y, Wolf BA: Leucine metabolism in regulation of insulin secretion from pancreatic beta cells. Nutr Rev 2010;68:270-279.

40 Polak P, Hall MN: mTOR and the control of whole body metabolism. Curr Opin Cell Biol 2009;21:209-218.

41 Polak P, Cybulski N, Feige JN, Auwerx J, Ruegg MA, Hall MN: Adipose-specific knockout of raptor results in lean mice with enhanced mitochondrial respiration. Cell Metab 2008;8:399-410.

-42 Raiten DJ, Raghavan R, Kraemer K: Biomarkers in growth. Ann Nutr Metab 2013;63:293297.
43 Hellmuth C, Demmelmair H, Schmitt I, Peissner W, Bluher M, Koletzko B: Association between plasma nonesterified fatty acids species and adipose tissue fatty acid composition. PLoS One 2013;8:e74927.

$\checkmark 44$ Hellmuth C, Koletzko B, Peissner W: Aqueous normal phase chromatography improves quantification and qualification of homocysteine, cysteine and methionine by liquid chromatography-tandem mass spectrometry. J Chromatogr B Analyt Technol Biomed Life Sci 2011;879:83-89.

45 Hellmuth C, Uhl O, Segura-Moreno M, Demmelmair $\mathrm{H}$, Koletzko B: Determination of acylglycerols from biological samples with chromatography-based methods. J Sep Sci 2011;34:3470-3483.

46 Hellmuth C, Weber M, Koletzko B, Peissner $\mathrm{W}$ : Nonesterified fatty acid determination for functional lipidomics: comprehensive ultrahigh performance liquid chromatographytandem mass spectrometry quantitation, qualification, and parameter prediction. Anal Chem 2012;84:1483-1490.

-47 Reinehr T, Wolters B, Knop C, Lass N, Hellmuth C, Harder U, Peissner W, Wahl S, Grallert H, Adamski J, Illig T, Prehn C, Yu Z, Wang-Sattler R, Koletzko B: Changes in the serum metabolite profile in obese children with weight loss. Eur J Nutr 2014, Epub ahead of print.

48 Harder U, Koletzko B, Peissner W: Quantification of 22 plasma amino acids combining derivatization and ion-pair LC-MS/MS. J Chromatogr B Analyt Technol Biomed Life Sci 2011;879:495-504.

49 Niesser M, Harder U, Koletzko B, Peissner W: Quantification of urinary folate catabolites using liquid chromatography-tandem mass spectrometry. J Chromatogr B Analyt Technol Biomed Life Sci 2013;929:116-124.

50 Deaton AM, Bird A: CpG islands and the regulation of transcription. Genes Dev 2011;25: 1010-1022.

51 Choi S-W, Friso S: Epigenetics: a new bridge between nutrition and health. Adv Nutr 2010; $1: 8-16$.

52 Gambari R, Fabbri E, Borgatti M, Lampronti I, Finotti A, Brognara E, Bianchi N, Manicardi A, Marchelli R, Corradini R: Targeting microRNAs involved in human diseases: a novel approach for modification of gene expression and drug development. Biochem Pharmacol 2011;82:1416-1429.

53 Sato F, Tsuchiya S, Meltzer SJ, Shimizu K: MicroRNAs and epigenetics. FEBS J 2011;278: 1598-1609.

54 Relton CL, Davey Smith G: Epigenetic epidemiology of common complex disease: prospects for prediction, prevention, and treatment. PLoS Med 2010;7:e1000356.

55 Sebert S, Sharkey D, Budge H, Symonds ME: The early programming of metabolic health: is epigenetic setting the missing link? Am J Clin Nutr 2011;94:1953S-1958S. 
56 Bateson P, Barker D, Clutton-Brock T, Deb D, D'Udine B, Foley RA, Gluckman P, Godfrey K, Kirkwood T, Lahr MM, McNamara J, Metcalfe NB, Monaghan P, Spencer HG, Sultan SE: Developmental plasticity and human health. Nature 2004;430:419-421.

-57 Waterland RA, Kellermayer R, Rached M-T, Tatevian N, Gomes MV, Zhang J, Zhang L, Chakravarty A, Zhu W, Laritsky E, Zhang W, Wang X, Shen L: Epigenomic profiling indicates a role for DNA methylation in early postnatal liver development. Hum Mol Genet 2009;18:3026-3038.

58 Reik W, Dean W, Walter J: Epigenetic reprogramming in mammalian development. Science 2001;293:1089-1093.

59 Dolinoy DC, Huang D, Jirtle RL: Maternal nutrient supplementation counteracts bisphenol A-induced DNA hypomethylation in early development. Proc Natl Acad Sci 2007; 104:13056-13061.

-60 Carone BR, Fauquier L, Habib N, Shea JM, Hart CE, Li R, Bock C, Li C, Gu H, Zamore PD, Meissner A, Weng Z, Hofmann HA, Friedman N, Rando OJ: Paternally induced transgenerational environmental reprogramming of metabolic gene expression in mammals. Cell 2010;143:1084-1096.

61 Crider KS, Yang TP, Berry RJ, Bailey LB: Folate and DNA methylation: a review of molecular mechanisms and the evidence for folate's role. Adv Nutr 2012;3:21-38.

62 Parle-McDermott A, Ozaki M: The impact of nutrition on differential methylated regions of the genome. Adv Nutr 2011;2:463-471.

-63 Godfrey KM, Sheppard A, Gluckman PD, Lillycrop KA, Burdge GC, McLean C, Rodford J, Slater-Jefferies JL, Garratt E, Crozier SR, Emerald BS, Gale CR, Inskip HM, Cooper C, Hanson MA: Epigenetic gene promoter methylation at birth is associated with child's later adiposity. Diabetes 2011;60:1528-1534.

-64 Seki Y, Williams L, Vuguin PM, Charron MJ: Minireview: epigenetic programming of diabetes and obesity: animal models. Endocrinology 2012;153:1031-1038.

- 65 Engeham SF, Haase A, Langley-Evans SC: Supplementation of a maternal low-protein diet in rat pregnancy with folic acid ameliorates programming effects upon feeding behaviour in the absence of disturbances to the methionine-homocysteine cycle. Br J Nutr 2010;103:996-1007.

66 Alexander BT: Epigenetic changes in gene expression: focus on 'the liver $\mathrm{X}$-receptor gene promoter is hypermethylated in a mouse model of prenatal protein restriction'. Am J Physiol Regul Integr Comp Physiol 2010; 298:R272-R274.
67 Burdge GC, Lillycrop KA, Phillips ES, SlaterJefferies JL, Jackson AA, Hanson MA: Folic acid supplementation during the juvenile-pubertal period in rats modifies the phenotype and epigenotype induced by prenatal nutrition. J Nutr 2009;139:1054-1060.

68 Gong L, Pan Y-X, Chen H: Gestational low protein diet in the rat mediates Igf2 gene expression in male offspring via altered hepatic DNA methylation. Epigenetics 2010;5:619626.

69 Hoile SP, Lillycrop KA, Thomas NA, Hanson MA, Burdge GC: Dietary protein restriction during F0 pregnancy in rats induces transgenerational changes in the hepatic transcriptome in female offspring. PLoS ONE 2011; 6:e21668.

70 Jousse C, Parry L, Lambert-Langlais S, Maurin A-C, Averous J, Bruhat A, Carraro V, Tost J, Letteron P, Chen P, Jockers R, Launay J-M, Mallet J, Fafournoux P: Perinatal undernutrition affects the methylation and expression of the leptin gene in adults: implication for the understanding of metabolic syndrome. FASEB J 2011;25:3271-3278.

71 Lillycrop KA, Phillips ES, Jackson AA, Hanson MA, Burdge GC: Dietary protein restriction of pregnant rats induces and folic acid supplementation prevents epigenetic modification of hepatic gene expression in the offspring. J Nutr 2005;135:1382-1386.

72 Lillycrop KA, Phillips ES, Torrens C, Hanson MA, Jackson AA, Burdge GC: Feeding pregnant rats a protein-restricted diet persistently alters the methylation of specific cytosines in the hepatic PPAR alpha promoter of the offspring. Br J Nutr 2008;100:278-282.

73 Lillycrop KA, Slater-Jefferies JL, Hanson MA, Godfrey KM, Jackson AA, Burdge GC: Induction of altered epigenetic regulation of the hepatic glucocorticoid receptor in the offspring of rats fed a protein-restricted diet during pregnancy suggests that reduced DNA methyltransferase-1 expression is involved in impaired DNA methylation and changes in histone modifications. Br J Nutr 2007;97:10641073.

74 Slater-Jefferies JL, Lillycrop KA, Townsend PA, Torrens C, Hoile SP, Hanson MA, Burdge GC: Feeding a protein-restricted diet during pregnancy induces altered epigenetic regulation of peroxisomal proliferator-activated receptor-alpha in the heart of the offspring. J Dev Orig Health Dis 2011;2:250-255.
75 van Straten EME, Bloks VW, Huijkman NCA, Baller JFW, van Meer H, Lütjohann D, Kuipers F, Plösch T: The liver X-receptor gene promoter is hypermethylated in a mouse model of prenatal protein restriction. Am J Physiol Regul Integr Comp Physiol 2010; 298:R275-R282.

76 Lillycrop KA, Burdge GC: Epigenetic changes in early life and future risk of obesity. Int $J$ Obes 2011;35:72-83.

-77 Groom A, Potter C, Swan DC, Fatemifar G, Evans DM, Ring SM, Turcot V, Pearce MS, Embleton ND, Smith DG, Mathers JC, Relton CL: Postnatal growth and DNA methylation are associated with differential gene expression of the TACSTD2 gene and childhood fat mass. Diabetes 2011;61:391-400.

78 Fryer AA, Emes RD, Ismail KMK, Haworth KE, Mein C, Carroll WD, Farrell WE: Quantitative, high-resolution epigenetic profiling of CpG loci identifies associations with cord blood plasma homocysteine and birth weight in humans. Epigenetics 2011;6:86-94.

79 Steegers-Theunissen RP, Obermann-Borst SA, Kremer D, Lindemans J, Siebel C, Steegers EA, Slagboom PE, Heijmans BT: Periconceptional maternal folic acid use of $400 \mu \mathrm{g}$ per day is related to increased methylation of the IGF2 gene in the very young child. PLoS One 2009; 4:e7845.

80 Almén MS, Jacobsson JA, Moschonis G, Benedict C, Chrousos GP, Fredriksson R, Schiöth HB: Genome wide analysis reveals association of a FTO gene variant with epigenetic changes. Genomics 2012;99:132-137.

81 Chernausek SD: Update: consequences of abnormal fetal growth. J Clin Endocrinol Metab 2012;97:689-695.

- 82 Koletzko B, Kolacek S, Phillips A, Troncone R, Vandenplas Y, Baumann U, van Goudoever J, de Swarte C, Benninga M, Mearin L: Research and the promotion of child health: a position paper of the European Society for Paediatric Gastroenterology, Hepatology and Nutrition. J Pediatr Gastroenterol Nutr 2014; 59:274-278.

83 Koletzko B, Benninga MA, Godfrey KM, Hornnes PJ, Kolacek S, Koletzko S, Lentze MJ, Mader S, McAuliffe FM, Oepkes D, Oddy WH, Phillips A, Rzehak P, Socha P, Szajewska $\mathrm{H}$, Symonds ME, Taminiau J, Thapar N, Troncone R, Vandenplas Y, Veereman G: Public-private collaboration in clinical research during pregnancy, lactation, and childhood: joint position statement of the Early Nutrition Academy and the European Society for Pediatric Gastroenterology, Hepatology, and Nutrition. J Pediatr Gastroenterol Nutr 2014;58:525-530. 